\title{
PERAN DAN FUNGSI KEPALA SEKOLAH DALAM MEWUJUDKAN SEKOLAH EFEKTIF DI LINGKUNGAN SEKOLAH DASAR
}

\author{
Triwahyu Riyatuljannah ${ }^{\mathbf{1}}$ \\ ${ }^{\perp}$ Jurusan Pendidikan Guru Madrasah Ibtidaiyah, Universitas Islam Negeri Sunan Kalijaga, \\ Indonesia \\ 18204080042@student.uin-suka.ac.id
}

Naskah diterima: 13 Desember, 2019, direvisi: 29 Juni, 2020, diterbitkan: 30 Agustus, 2020

\begin{abstract}
Educational leadership or principal is a regulator and director in an organization to improve performance. The leader has a responsibility to prompt the quality of human resources to be productive thus generate the effective school. This article depicts how the roles and functions of the principal as a developer of human resources to create an effective school. The purpose of this paper is to find out: 1) The components of system in primary school. 2) The characteristics and components of quality in primary school are predicated on effective school perspective. 3) The leadership dimension of educators in effective schools/madrasah. 4) The relevance of educational leadership and human resources development with effective schools. The research method uses descriptive qualitative with a case study approach. Data collection techniques through direct observation, documentation and in-depth interviews. Sources of data obtained from the principal. Data validity uses triangulation techniques and data analysis uses interactive analysis through the stages of data collection, data reduction, data presentation and concluding. The results showed that SDN Condongcatur 1 Yogyakarta Indonesia is an effective school and the development of equitable quality resources. The conclusion is the principal's leadership is the main indicator in creating an effective school.
\end{abstract}

Keywords: Educational leadership, Principal, Effective schools, Quality development

\section{ABSTRAK}

Kepemimpinan pendidikan adalah pengatur dan pengarah apa yang akan dituju dalam sebuah organisasi dalam meningkatkan kinerja sebagai faktor keberhasilan dan kontinuitas. Pemimpin mengupayakan peningkatan mutu SDM secara produktif sehingga dalam proses bimbingan belajar supaya bisa melahirkan sekolah yang memiliki mutu tinggi dan efektif. Peran dan fungsi kepemimpinan pendidikan dan pengembangan mutu SDM untuk mewujudkan sekolah efektif diuraikan dalam komponen penting. Tujuan dari penulisan ini adalah untuk mengetahui: 1) Komponen madrasah/sekolah sebagai sebuah sistem. 2) Karakteristik dan komponen mutu MI/SD dalam perspektif sekolah efektif. 3) Dimensi kepemimpinan pendidik pada sekolah/madrasah efektif. 4) Relevansi kepemimpinan pendidikan dan pengembangan SDM dengan sekolah efektif. Metode penelitian menggunakan metode kualitatif deskriptif dengan penekatan studi kasus. Teknik pengumpulan data melalui observasi langsung, dokumentasi dan wawancara mendalam. Sumber data diperoleh dari kepala sekolah. Validitas data menggunakan teknik triangulasi dan analisis data menggunakan analisis interaktif melalui tahapan pengumpulan data, reduksi data, sajian data dan penarikan kesimpulan. Hasil penelitian menunjukkan bahwa SDN Condongcatur 1 Yogyakarta merupakan sekolah yang efektif serta pengembangan mutu sumber daya yang merata. Simpulannya adalah kepemimpinan kepala sekolah merupakan indikator utama dalam mewujudkan sekolah efektif.

Kata Kunci: Kepemimpinan pendidikan, Pengembangan mutu, Sekolah efektif. 


\section{PENDAHULUAN}

Sekolah atau madrasah adalah lembaga pendidikan yang mempunyai fungsi sebagai penyelenggara pendidikan yang dirancang khusus untuk mendidik siswa melalui bimbingan guru sesuai dengan kebijakan dari pemerintah (Herawan, 2016). Perkembangan pendidikan sedang di publikasikan dengan manajemen peningkatan mutu SDM agar dapat mewujudkan sekolah yang efektif. Bertepatan dengan tantangan yang komprehensif, pendidikan adalah sesuatu yang substansial oleh sebab pendidikan adalah jalur penentu sumber daya manusia yang bermutu, kontributif, unggul dan memiliki nilai positif bagi pendidikan (Fitrah, 2017).

Perkembangan pendidikan menuntut agar sumber daya manusia diharapkan dapat mengikuti proses mutu pendidik yang sesuai dengan standar kompetensi sebagai pendidik. Maka adanya seorang pemimpin di sekolah mengupayakan sistem yang dapat memberdayakan seluruh pendidik sebagai sumber daya manusia dapat dilakukan secara optimal. Maka, tanggung jawab dan fungsi kepala sekolah selaku pemimpin harus berinovasi dan keratif untuk melaksanakan pemberdayaannya. Hal ini bisa dimulai dengan menyusun visi, misi, tujuan, hingga strategi pembelajaran agar dapat tercapainya mutu pendidikan.

Artikel ini berisi tentang peran dan fungsi kepemimpinan dalam mengembangkan mutu sumber daya manusia untuk mewujudkan sekolah efektif. Artikel ini akan menjelaskan lebih jauh tentang bagaimana komponen madrasah/sekolah sebagai sebuah sistem, karakteristik serta komponen mutu MI/SD dalam perspektif sekolah efektif, dan dimensi kepemimpinan pendidikan pada sekolah/madrasah efektif serta bagaimana relevansi kepemimpinan pendidikan dan pengembangan SDM dengan sekolah efektif.

\section{METODOLOGI}

Metode penelitian yang digunakan dalam penelitian ini adalah metode kualitatif deskriptif dengan pendekatan case study atau studi kasus di SDN Condongcatur 1 Yogyakarta Indonesia. Pendekatan kualitatif bertujuan untuk menemukan makna di balik fakta yang secara teliti, tidak sekedar deskripsi ideografis yang naratif. Teknik pengumpulan data melalui observasi langsung, dokumentasi dan wawancara mendalam. Sumber data adalah kepala sekolah SDN Condongcatur 1 Yogyakarta. Validitas data menggunakan teknik triangulasi sumber, teori dan metode. Sedangkan analisis data menggunakan analisis interaktif melalui tahapan pengumpulan data, reduksi data, sajian atau dan verifikasi atau penarikan kesimpulan. Pendalaman dan pemaknaan dilakukan oleh peneliti bagaimana sekolah yang efektif diselenggarakan di SDN Condongcatur 1 Yogyakarta terkait dengan peran dan fungsi kepemimpinan dan pengembangan mutu sumber daya manusia. Penelitian ini dilaksanakan pada bulan November 2019.

\section{HASIL DAN DISKUSI}

\section{A. Komponen Madrasah/Sekolah Sebagai Sebuah Sistem}

Pendidikan sebagai sistem tentu tidak terlepas dari keterikatan dengan berbagai sistem kehidupan yang lain. Sebagai contoh dalam sistem adalah kehidupan berbangsa, keluarga, pemerintah dan masyarakat. Begitu pula dengan sekolah adalah suatu aturan, yang memiliki berbagai komponen yang didalamnya mempunyai keterkaitan dan terikat antara komponen yang satu dengan komponen yang lain (Ondi \& Sobarudin, 2015).

Peran sekolah sangat strategis dalam membentuk kualitas generasi muda di masa depan. Inti kegiatan sistem sekolah paling tidak memiliki dua tujuan utama yaitu mendidik peserta didik dalam berbagai macam akademik atau keterampilan pengetahuan, mendidik 
peserta didik dalam mengembangkan personal dan keterampilan sosial serta pengetahuan yang dibutuhkan untuk pekerjaan dan sosial politik di masyarakat (Anzizhan, 2004).

Seluruh masukan pendidikan yang selanjutnya disusun akan menjadi bagian satu sama lain yang fungsional dalam mencapai tujuan. Bagian yang memiliki fungsi tertentu dalam mencapai tujuan sistem pendidikan bisa disebut sebagai komponen pendidikan. Dalam proses pendidikan terdapat komponen pendidikan yang mampu membentuk pola interaksi. Komponen pendidikan (Syafril \& Zen, 2017) tersebut sebagai berikut:

1. Tujuan

Tujuan adalah komponen pendidikan yang mempunyai kedudukan yang luar biasa dalam berjalannya pendidikan. Seluruh tujuan sifatnya bagus, maksudnya tidak berlawanan dengan esensi perkembangan siswa dan bisa dibenarkan sebagai etika yang baik. Dalam tujuan pendidikan ada yang sifatnya sempurna dan sesuai realita. Jika sempurna umumnya dirumuskan dalam bentuk tujuan pendidikan yang sifatnya general, sementara itu realita dirumuskan dalam bentuk khusus.

2. Pendidik

Pendidik ialah orang yang memiliki tanggung jawab atas pelaksanaan pendidikan. Wali murid atau orangtua biasa disebut sebagai pendidik menurut kodrat. Sedangkan guru selaku pendidikan menurut jabatan yang mematuhi tanggung jawab mendidik dari tiga pihak, yaitu negara, orangtua dan masyarakat. Pendidik memiliki tugas yang cukup berat, maka sebagai pendidik harus memiliki bakat, kesehatan jasmani, bahasa yang sopan, kepribadian yang kuat, disenangi oleh peserta didik. Pendidik tidak hanya sebagai guru didalam kelas, namun memiliki hubungan yang erat antara pendidik dan peserta didik diluar kelas.

3. Peserta Didik

Peserta didik dipakai berlandasan perspektif manusia yaitu makhluk yang memiliki kepribadian. Istilah tersebut digunakan mengingat pendidikan ialah suatu proses pendidikan, penyesuaian diri dan pemecahan masalah. Peserta didik ialah makhluk yang mempunyai kecerdikan atau kompetensi yang selalu menghadapi perkembangan dan perubahan secara bertahap.

4. Materi

Materi yang akan disampaikan haruslah sesuai dengan tujuan pendidikan, berisi nilai yang serasi dengan pandangan hidup bangsa. Memilih materi harus sesuai dengan kompetensi peserta didik, memikat perhatian, ketertarikan, usia, kemampuan, jenis kelamin, background dan experience. Lain daripada hal tersebut, materi juga harus distrukturkan sesuai sintak dengan melihat kesetaraan dari yang sederhana hingga lebih spesifik sehingga memudahkan untuk dipelajari dan melahirkan kurikulum.

5. Metode, Media dan Alat Pendidikan

a. Metode

Metode yaitu cara yang memiliki fungsi sebagai instrumen dalam meraih tujuan pembelajaran. Untuk menggunakan metode apakah bisa dipakai atau kurang tepat. Hal tersebut dipengaruhi dari berbagai elemen diantaranya adalah tujuan yang akan diperoleh, faktor peserta didik dan faktor pendidik.

b. Media

Media ialah seluruh bahan yang dipakai untuk menyampaikan pesan dari guru pada peserta didik agar dapat menstimulus daya pikir, pandangan, ketertarikan dan minat peserta didik selama proses kegiatan belajar. 


\section{c. Alat Pendidikan}

Proses pembelajaran pasti menggunakan instrumen pendidikan, yaitu seluruh hal yang bisa atau mampu membantu mewujudkan tercapainya tujuan pendidikan.

6. Lingkungan Pendidikan

Lingkungan berarti mencakup seluruh kondisi sekitar dengan cara tertentu yang mampu menguasai tingkah laku, pertumbuhan, perkembangan atau life process. Sesuatu yang dapat berpengaruh bisa bermula dari dalam jiwa peserta didik ataupun luar diri peserta didik. Lingkungan pendidikan dapat dibedakan menjadi tiga yaitu keluarga, masyarakat dan sekolah. Seluruh komponen yang ada merupakan satu kesatuan yang saling berkaitan dengan kompenen lainnya dalam proses pendidikan. Maka dalam melaksanakan sistem pendidikan, komponen tersebut harus menjadi prioritas utama. Karena komponen merupakan potongan dari sebuah proses yang menentukan tercapai atau tidaknya pendidikan.

\section{B. Karakteristik dan Komponen Mutu MI/SD dalam Perspektif Sekolah Efektif}

Evaluasi efektivitas sekolah dilaksanakan melalui langkah analisis bagaimana semua elemen sekolah dapat berjalin satu sama lain secara harmonis dalam menjungjung kompetensi peserta didik. Banyak penelitian yang telah dilaksanakan untuk mengetahui tingkat efektivitas sekolah seperti aspek input, proses dan outputloutcome. Maka, hasil pendidikan yang bermutu didapat oleh peserta didik berupa potensi akademik yang tinggi.

Ada beberapa karakteristik sekolah efektif, yaitu kepemimpinan instruksional, mengaplikasikan fungsi-fungsi manajemen, fokus pada tujuan dan kenyamanan pendidik. Kualifikasi keefektifan sekolah maka terdapat tiga bagian diantaranya: (1) taraf sekolah, kepemimpinan sekolah mengaplikasikan fungsi manajemen, (2) taraf kelas, kesiapan pendidik dalam mengaktualkan tugas mengajar, mendidik dan membimbing, (3) taraf peserta didik, sebagai output dan hasil belajar (Riswandi, 2015). Adapun karkteristik sekolah efektif (Ondi \& Sobarudin, 2015), beberapa negara seperti Australia, Amerika Serikat, Belanda dan Inggris merumuskan 10 karakteristik sekolah efektif sebagai berikut:

Tabel 1. Karakteristik Sekolah Efektif

\begin{tabular}{ll}
\hline \multicolumn{1}{c}{ Aspek } & \multicolumn{1}{c}{ Indikator } \\
\hline Profesional leadership & Firm and Purposeful \\
& A participate approach \\
& The leading professional \\
Shared vision and goals & Unity of purpose \\
& Consistency of practice \\
& Collegiality and collaboration \\
A learning environment & An orderly atmosphere \\
& An attractive working environment \\
& Maximization of learning time \\
& Academic emphasi \\
Learning & Focus on acihievment \\
Purposeful teaching & High expectation all round \\
& Communication expectation \\
Positive reinforcement & Providing intellectual challenge \\
& Clear and fair dicipline \\
Monitoring progress & Feedback \\
& Monitoring pupil performance \\
Pupils right & Evaluating school performance \\
responsibilities & Reising pupil self-esteem \\
& Position of responsibility \\
& Control of work
\end{tabular}




\begin{tabular}{ll}
\hline Home/school partnership & $\begin{array}{l}\text { Parental involvment in their } \\
\text { childern's learning }\end{array}$ \\
A Learning organization & School-based staff development
\end{tabular}

Sumber: Ondi \& Sobarudin, 2015

Sedangkan menurut Edmons (Sapa'at, 2012) menyebutkan bahwa karakteristik sekolah efektif ada lima poin, diantaranya adalah sebagai berikut:

1. Kekuasaan dan kehendak/minat kepala sekolah terhadap kualitas pengajaran.

2. Pengetahuan yang mengakar mengenai pendidikan.

3. Lingkungan yang tentram dan teratur bagi berjalannya pengajaran dan pembelajaran

4. Impian seluruh peserta didik cikal bakal menginterpretasikan seluruh ilmu pengetahuan

5. Asesmen peserta didik yang didasarkan pada hasil evaluasi belajar peserta didik

Apabila dihubungkan antara semua faktor sekolah efektif, maka terlihat jelas bahwa seluruh faktor tersebut hanya patokan sebagai sekolah yang memburu mutu pendidikan. Karena pendidikan bukan hanya sebatas prestasi peserta didik namun keberhasilan non akademik sebagai peningkatan semangat belajar. Selain itu dukungan dari berbagai pihak akan membantu sekolah efektif dapat mencapai keberhasilannya.

Efektivitas sekolah dapat ditunjukan dengan adanya proses dari berbagai sumber dan strategi yang diarahkan hingga berlangsungnya kegiatan belajar di sekolah. Efektivitas sekolah menunjukkan kapabilitas seluruh elemen di sekolah sebagai naungan belajar dan kegunaan pada rancangan kegiatan yang sudah terstruktur. Tujuannya ialah peserta didik mampu memperoleh kompetensi yang sudah dipastikan dan bermutu tingi.

Dalam menggapai tujuan pelaksanaan sekolah efektif dibutuhkan penyelenggaraan sekolah yang harmonis dengan kondisi dan situasi lokasi sekolah dilaksanakan. Pada proses pengelolaan sekolah, sebagai pemimpin perlu memberikan atensi pada faktor informal, faktor simbolik dan faktor yang tak terlihat dari keberlangsungan sekolah yang sudah menciptakan kepercayaan serta langkah setiap penduduk sekolah (Raharjo \& Yuliana, 2016).

Membahas mengenai mutu sudah pasti membahas barang. Mutu yang baik sudah pasti memiliki nilai untuk seseorang yang secara fisik memiliki keindahan dan tidak ada cacat. Mutu adalah istilah subjektif dan relatif yang didefinisikan dan didukung oleh pendapat yang sama baiknya (Engkoswara \& Komariah, 2010). Seperti yang tercantum dalam Peraturan Pemerintah No. 32 tahun 2013 tentang Standar Nasional Pendidikan (Indonesia, 2013) yang terdiri dari 8 standar, yaitu:

1. Standar Pengelolaan

Standar pengelolaan untuk satuan pendidikan dasar dan menengah adalah standar pengelolaan pendidikan untuk sekolah/madrasah yang berkaitan dengan perencanaan, pelaksanaan dan pengawasan kegiatan pendidikan agar tercapai efisiensi dan afektivitas penyelenggaraan pendidikan.

2. Standar Kompetensi Lulusan

Standar kompetensi lulusan adalah kualifikasi kemampuan lulusan yang mencakup sikap, pengetahuan dan keterampilan.

3. Standar Isi

Standar isi adalah ruang lingkup materi dan tingkat kompetensi yang dituangkan dalam kriteria tentang kompetensi tamatan, kompetensi bahan kajian, kompetensi mata pelajaran dan silabus pembelajaran yang harus dipenuhi oleh peserta didik pada jenjang dan jenis pendidikan. 
4. Standar Proses

Standar proses adalah standar nasional yang berkaitan dengan pelaksanaan pembelajaran pada satu kesatuan pendidikan untuk mencapai standar kompetensi lulusan.

5. Standar Pendidik dan Tenaga Kependidikan

Standar pendidik dan tenaga kependidikan adaah kriteria prajabatan dan kelayakan fisik maupun mental, serta pendidikan dalam jabatan.

6. Standar Sarana dan Prasarana

Standar sarana dan prasarana adalah standar nasional pendidikan yang berkaitan dengan kriteria minimal tentang ruang belajar, tempat beribadah, tempat berolah raga, perpustakaan, laboratorium, bengkel kerja, tempat bermain dan tempat berekreasi serta sumber lain yang menunjang pembelajaran termasuk penggunaan teknologi informasi dan komunikasi.

7. Standar Pembiayaan

Standar pembiayaan adalah standar yang mengatur komponen dan biaya operasi yang berlaku selama satu tahun.

8. Standar Penilaian

9. Standar penilaian pendidikan adalah kriteria mengenai mekanisme, prosedur dan instrumen penilaian hasil belajar peserta didik.

Dengan demikian, tata kelola sekolah yang efektif perlu mengikutsertakan seluruh elemen di sekolah agar dapat tercapainya visi sekolah pada sekolah yang unggul dalam prestasi dan kenyamanan pada pengguna pendidikan.

\section{Dimensi Kepemimpinan Pendidikan pada Sekolah/Madrasah Efektif}

Tercapainya kesuksesan suatu organisasi selalu terkait dengan seorang pemimpin, yaitu pengatur dan mengarahkan apa yang akan dicapai oleh sebuah organisasi pada tujuan yang akan dituju. Jiwa kepemimpinan dalam meningkatkan kinerja ialah faktor keberhasilan dan kontinuitas organisasi, hal ini menentukan kuat atau tidaknya peran kepemimpinan yang melingkupi pembentukan guru, staf, siswa, orangtua, dan fasilitator.

Selain sebagai pemimpin di sekolah, ia perlu merumuskan adanya sebuah perencanaan program sekolah agar tercapai tujuan yang diharapkan. Seperti yang telah diatur dalam Permendiknas No. 19 tahun 2007 bahwa Standar perencanaan program tersebut meliputi: perumusan dan penetapan visi, misi, tujuan dan berpedoman pada standar yang telah ditetapkan oleh pemerintah diharapkan dapat terciptanya perencanaan program sekolah secara efektif dan efisien (Lubis, 2017).

Karakteristik yang harus dimiliki pemimpin saat memimpin pendidikan ialah mampu bertransformasi, selain itu efektivitas kinerja pemimpin beralsan pada unsur humanistik yang berwujud pemberdayaan pendidik juga mempunyai keahlian memajukan organisasi. Kecerdasan emosional salah satu faktor kemampuan yang dimiliki pemimpin untuk mengatur jalannya sebuah organisasi. Landasan moral pun menjadi pijakan untuk dapat mengkonstruk komunikasi yang baik diantara personil pendidik di sekolah. Karakteristik transformasional diantaranya ialah rasa yang teguh pada moral, dinamika perubahan, kecerdasan emosional, komitmen, dan berbagi keahlian yang dimiliki masing-masing personil pendidik (Rohmat, 2010).

Dalam beberapa studi mengenai berhasil dan efektifnya sekolah (School effectiveness) sudah diidentifikasi dari beberapa karakteristik sekolah sukses. Cheng mengatakan, sekolah dapat disebut efektif apabila memiliki kapasitas untuk memaksimalkan pencapaian tujuan dan fungsi sekolah. Edmond menyatakan bahwa sekolah yang efektif bisa dinilai dari 
perubahan-perubahan yang terdapat pada karakteristik organisasional sekolahnya, hal ini mencakup pendidikan dasar, kepemimpinan instruksional, ekspetasi akademik, ketertiban dan suasana sekolah yang memiliki nilai positif (Raihani, 2011).

Kepempinan merupakan hal yang krusial untuk membangun dan mengefektifkan sekolah. Sekolah dapat terlaksana secara efektif jika kepala sekolah dapat tercipta suasana tertib, disiplin dan memiliki tujuan suasana antara pendidik dan peserta didik. Menurut Beck dan Murphy (Raihani, 2011), ada empat imperatif bagi sekolah sukses:

1. Imperatif untuk mengembangkan pembelajaran secara spesifik namun tidak ekslusi untuk peserta didiknya.

2. Imperatif bagi individu untuk mengemban pekerjaan kepempinan serta memusatkan energi dan sumber dari stakeholder secara produktif.

3. Imperatif untuk menjaga suasana yang baik di sekolah dan menggabungkan sekolah dengan masyarakat dengan sistem simbosis mutualisme.

4. Imperatif untuk mendukung usaha membangun staf administrasi, pendidik dan orang tua agar bisa menyuport pembelajaran peserta didik.

Dari empat poin imperatif tersebut memiliki keterkaitan dengan karakteristik sekolah sukses, yaitu dikonseptualisasikan oleh Wisconsin Departement of Public Instructional. Karakteristik yang menjadi tambahan mencakup visi, kepemimpinan, standar akademik, standar sikap dan emosi, keluarga, sekolah, mitra komunitas, perkembangan profesional serta bukti keberhasilan. Jika poin imperatif tersebut terousat pada proses sekolah sebagai tolak ukur untuk menilai efektivitas, maka Wisconsin Departement of Public Instructional memberi penekanan agar disertakan bukti hasil prestasi peserta didik sebagai karakteristik sekolah yang efektif.

Sekolah efektif sendiri ialah sekolah yang mampu memenuhi kebutuhan yang diidentifikasi secara lokal dari sumber daya yang tersedia dan menjamin peserta didik datang secara teratur dan tentu mempunyai hasil tes yang baik. Sekolah yang efektif lebih memusatkan pada kualitas hasil bukan pada proses kualitas hasil. Sekolah akan memiliki predikat efektif apabila memiliki seorang pemimpin yang kuat, partisipasi orang tua peserta didik dalam proses yang dilaksanakan di sekolah, bebas dari kontrol dan aturan eksternal yang melampaui, serta tentunya pendidik yang berkualitas (Marini, 2017).

Sekolah efektif dan sukses dikarakteristik dengan beberapa faktor yang kait eratannya dengan sasaran sekolah dan strategi untuk mencapainya. Sasaran sekolah akan tepat disaaat sasaran tersebut menitikberatkan pada hasil siswa dan strategi digunakan untuk mencapai sasaran yang mengacu pada proses di sekolah. Sekolah dapat sukses dan efektif mencakup kejelasan visi, misi, tujuan dan arah strategi yang mendukung untuk menciptakan suasana belajarn yang mudah diterima peserta didik.

\section{Relevansi Kepemimpinan Pendidikan dan Pengembangan SDM dengan Sekolah Efektif}

Pegembangan merupakan usaha melenyapkan kesenjangan antara skill SDM dengan yang diharapkan dari suatu organisasi. Usaha tersebut dilaksanakan melalui peningkatan skill yang sudah dimiliki oleh pegawai dengan cara memperbanyak wawasan dan keterampilan serta merubah perilaku. Andrew F. Sikula (Zuhri, 2014) mengatakan bahwa:

"Development in reference to staffing and personel matters, is a long term educational process utilizing a systematic and organized procedure by which managerial persnel learn conceptual and theoretical knowledge for general pruposes"

Maksud dari yang disebutkan oleh Andrew adalah pengembangan yang merujuk pada masalah SDM dan individu ialah sebuah usaha untuk mengembangkan potensi dan keahlian 
dalam jangka waktu yang panjang serta dapat memanfaatkan langkah yang terstruktur dan teroganisir dimana pegawai dapat meningkatkan pendidikan secara konseptual, pengetahuan teoritis serta moral untuk mencapai tujuan.

Sumber daya manusia di dalam sebuah organisai merupakan hal yang penting serta fundamental bagi berlangsungnya sebuah organisasi. Tanpa dukungan manusia, tentunya organisasi tidak akan berjalan karena sebuah organisasi dapat melakukan manajemennya apabila dilaksanakan oleh manusia yang memiliki kualitas Lain daripada itu SDM yang dibutuhkan harus di rencanakan terlebih dulu karena SDM bagi manajemen organisasi ialah kegiatan yang memiliki value, krusial dan rentan (Suhardiman, 2012). Hal-hal yang harus diperhatikan dalam pemberdayaan tenaga kependidikan sebagai sumber daya manusia yang berpengaruh pada produktivitas kerja dan upaya pengembangannya antara lain:

1. Sikap mental tenaga kependidikan

2. Tingkat kependidikan

3. Penghargaan (Reward)

4. Hubungan antara pegawai

5. Kesempatan berprestasi

6. Lingkungan dan suasana kerja

7. Jaminan sosial dan kesehatan (Yusraini, 2012)

Pengembangan sumber daya manusia memiliki tujuan yaitu untuk meningkatkan kualitas profesional dan terampil saat melaksanakan tugasnya. Maka didalam sebuah organisasi harus mengupayakan pengembangan sumber daya manusia, karena investasi dalam pengembangan sumber daya manusia yang dihadapkan bagi perbaikan kompetensi yang berguna pada diri manusia. Adapun tujuan dan manfaat (Hasibuan, 2016) pengembangan sumber daya manusia sebagai berikut:

Tabel 2. Tujuan dan Manfaat Pengembangan SDM

\begin{tabular}{|c|c|c|}
\hline No & Tujuan Pengembangan & Manfaat Pengembangan \\
\hline 1 & Produktivitas kerja & $\begin{array}{l}\text { - Produktivitas pegawai meningkat } \\
\text { - } \text { Technical skill, human skill dan managerial } \\
\text { skill semakin baik } \\
\text { - Kualitas dan kuantitas produksi semakin baik }\end{array}$ \\
\hline 2 & Efisiensi & $\begin{array}{l}\text { - Meningkatkan efisiensi tenaga, waktu dan } \\
\text { bahan baku } \\
\text { - Biaya relatif kecil sehingga saya saing } \\
\text { semakin besar } \\
\text { - Pemborosan berkurang }\end{array}$ \\
\hline 3 & Moral & $\begin{array}{l}\text { - Keahlian sesuai dengan pekerjaan } \\
\text { - Antusiasme meningkat }\end{array}$ \\
\hline 4 & Karir & $\begin{array}{l}\text { - Peluang meningkatkan karir semakin besar } \\
\text { - Promosi ilmiah didasarkan pada keahlian dan } \\
\text { prestasi kerja }\end{array}$ \\
\hline 5 & Konseptual & $\begin{array}{l}\text { - Manajer semakin cakap dalam mengambil } \\
\text { keputusan }\end{array}$ \\
\hline 6 & Kepemimpinan & $\begin{array}{l}\text { - Kepemimpinan manajer semakin baik } \\
\text { - Human relations lebih fleksibel } \\
\text { - Motivasi terarah } \\
\text { - Kooperatif semakin harmonis }\end{array}$ \\
\hline 7 & Balas Jasa & $\begin{array}{l}\text { - Balas jasa akan meningkat karena prestasi } \\
\text { kerja semakin besar }\end{array}$ \\
\hline 8 & Konsumen & $\begin{array}{l}\text { - Kepuasan konsumen karena mutu dan pelayan } \\
\text { semakin baik }\end{array}$ \\
\hline
\end{tabular}

Sumber: Hasibuan, 2016 
Berdasarkan Tabel 2, tujuan dan manfaat pengembangan pendidik sebagai sumber daya manusia agar dapat menjadi individu yang bermutu. Pemimpin akan mendorong pendidik untuk dapat mengembangkan potensi keterampilan dan keahlian yang dimilikinya. Sehingga diantara sesama pendidik memiliki daya saing yang kompetitif .

Pengembangan pada dasarnya adalah sebuah proses perubahan agar terdapatnya peningkatkan kesejahteraan dan kualitas sumber daya manusia. Adapun moralitas sangat dibutuhkan dalam menjalani pekerjaannya karena nilai ini mengenai dengan baik dengan tidak baik, benar dan tidak benar. Jadi kualitas sumber daya manusia tidak hanya sebatas kemampuan dan daya kreatifnya tetapi juga oleh moralitasnya.

Pengelolaan sumber daya manusia seringkali dianggap sebagai tanggung jawab yang harus di emban oleh lembaga tertentu atau hanya pimpinan dari sekolah.memilih, mendukung dan menjaga kualitas sumber daya manusia adalah hal yang disebut dengan administrasi sumber daya manusia tingkat sekolah. Tidak hanya memilih kualitas sumber daya manusia, kepala sekolah pun memengaruhi kualitas berjalannya sistem di sekolah. waktu yang dipakai dalam bekerja, interaksi, hubungan profesional, pendanaan, penempatan sumber daya, dan segala tanggung jawab memunculkan efek yang berdurasi lama terhadap sekolah yang dipimpinnya (Stronge, Richard, \& Catano, 2013).

Beberapa peran sebagai pemimpin dalam pengembangan mutu SDM mencakup pembentukan suatu tim penjaminan mutu, menyusun strategi dan kebijakan mutu, pengaplikasian dan penyebar luasan tujuan sasara mutu, penyediaan dan pembagian sumber daya, pengembangan pendidikan dan pelatihan, penetapan tim perbaikan mutu, pengkondisian perbaikan mutu secara terus-menerus dan memberikan reward pada sumber daya yang bermutu sesuai dengan standar organisasi. Pengembangan sumber daya manusia ialah agenda yang perlu dilaksanakan oleh suatu organisasi, agar kompetensi kognitif, kemampuan dan keahlian sumber daya yang diharapkan sesuai dengan tuntutan pekerjaan yang akan dilakukan (Hijriah, 2016).

Kehadiran seorang pemimpin di sebuah organisasi sangat diperlukan untuk memboyong organisasi pada tujuan yang sudah ditetapkan. Bermacam corak kepemimpinan akan membentuk tata krama pemimpin dalam melaksanakan tanggung jawabnya. Bagimanapun cara seorang pemimpin tentu akan megarahkan kepemimpinannya untuk kepentingan bersama. Kepemimpinan berdasarkan pada kekayaan konseptual dengan cara menyebutkan (teling), jual (selling), partisipasi (participating), mendelegasikan (delegating). Mengatakan, berarti pemimpin memberitahukan dan menjelaskan peran dan tugas yang harus dikerjakan bawahannya.

Menjual berarti pemimpin memberikan intruksi pada bawahannya dan mendukung agar tidak salah dalam menjalankan tugasnya. Partisipasi berati pemimpin dan bawahan saling membagi dalam mencari keputusan agar timbul solusi yang baik. Delegasi berati memberikan pengarahan secara personal kepada bawahannya dalam menjalankan perannya (Hijriah, 2016).

Dengan demikian, untuk memperoleh efektifitas dan efisiensi dalam mengembangkan dalan memberdayakan sumber daya manusia tentu harus dilaksanakan secara profesional. Pendidik sebagai sumber daya manusia yang profesional dapat bisa melakukan kegiatan belajar mengajar yang bermutu. Pembelajaran yang bermutu akan dapat meningkatkan aspek kognitif, afektif serta psikomotorik peserta didik. 


\section{E. Implementasi Kepemimpinan dalam Mewujudkan Sekolah Efektif di SDN Condongcatur Yogyakarta}

Salah satu peran kepala sekolah adalah sebagai pribadi yang memiliki nilai integritas dan berakhlak mulia, mengembangkan budaya, teladan, memiliki keinginan kuat, terbuka dalam melaksanakan tugasnya, bisa mengendalikan diri dalam pekerjaan, bakat dan minat jabatan sebagai kepala sekolah (Usman, 2011). Kepala sekolah SDN Condongcatur Yogyakarta, Bapak Tri Suhadi, memiliki nilai-nilai kepemimpinan yang menjadi energi positif dalam melaksanakan perannya sebagai pemimpin.

Memimpin secara efektif maka kepala sekolah mampu menjadi pemimpin yang efektif pula. Karakter dan nilai tersebut dapat memberikan semangat di hidup dan pekerjaannya. Nilai inilah yang akan mengalir dalam jiwa dan memancar kepada orang-orang di sekitarnya. Tanpa terasa jiwa yang dirasakan pemimpin akan tertanam pada peserta didik melalui guruguru di sekolah. Dalam menciptakan sekolah yang efektif, bermutu dan berkualitas maka kepala sekolah tentu memahami visi dan misi sekolah dengan baik dan tepat.

Visi dan misi yang baik adalah adalah yang dikembangakan dalam bentuk harapan dan cita-cita yang berwujud pada pencapaian sekolah. Secara rinci visi adalah pandangan jauh ke depan yang merupakan elaborasi rasional dan nilai yang diyakini, wujud nyata visi ini yaitu output lembaga pendidikan yang diharapkan berhasil optimal berlandasakan nilai-nilai agama didalam organisasi sekolah ini. Misi didefinisikan sebagai upaya untuk merubah keadaan sekarang menjadi keadaan di masa depan yang sesuai dengan rumusan visi.

Menurut kepala sekolah SDN Condongcatur Yogyakarta, visi dan misi dilaksanakan melalui pengimplementasian pendidikan yang baik. Hal ini perlu ditanamkan sejak dini, karena anak atau peserta didik di zaman sekarang akan menjadi calon pemimpin dimasa yang akan datang maka dari itu perlu untuk melanjutkan pendidikan ke jenjang berikutnya. Pendidikan ini tentu berpedoman pada kurikulum yang berlaku di sekolah, yaitu kurikulum 2013 dimana pendidikan karakter, ilmu pengetahuan dan teknologi berjalan beriringan.

Keberhasilan suatu organisasi biasanya ditentukan dari sejauhmana tujuan pendidikan dapat tercapai pada periode dimana pemimpin tersebut menjabat dan lamanya pendidikan berlangsung beriringan dengan kuriulum yang berlaku. Maka timbul adanya sekolah efektif. Selain fokus pada visi dan misi untuk menjadikan sekolah efektif, ada beberapa hal yang perlu dilakukan untuk mengoptimalkan sekolah efektif.

Langkah yang diterapkan oleh Bapak Tri Suhadi sebagai pemimpin dalam menciptakan sekolah efektif. Untuk meningkatkan mutu sekolah efektif menurut kepala sekolah yang pertama, tentunya yang menyangkut dengan prestasi akademik kompetensi guru dalam kinerjanya. Kedua, peran orangtua dan lingkungan sangat berpengaruh. Ketiga, peserta didik sendiri yang mendukung ketika dalam pembelajaran mengulang belajar di rumah dan tidak terpengaruh dengan dampak negatif teknologi. Sekolah adalah organisasi yang memiliki program yang saling berhubungan. Bosker dan Guldemon (Moerdiyanto, 2007) menyatakan sistem sekolah yang efektif terdiri dari 5 komponen yaitu konteks, input, proses, output dan outcome. Komponen ini direalisasikan saat wawancara dengan kepala sekolah SDN Condongcatur Yogyakarta (Suhadi, 2019) sebagai berikut:

\section{Konteks}

Kepala Sekolah SDN Condongcatur Yogyakarta memenuhi kebutuhan bagi masyarakat, yaitu memberikan pendidikan yang baik untuk masa depan peserta didiknya. Hal ini berupa sarana dan prasarana yang nyaman untuk proses pembelajaran, fasilitas yang mendukung untuk kegiatan belajar dan sebagainya. Begitu dengan kebijakan yang berlaku di SDN Condongcatur Yogyakarta, memberikan reward dan punishment bagi sumber daya manusia dan peserta didik. 
2. Input

Bagi para sumber daya manusia yang ada di sekolah, kepala sekolah membuat lingkungan bekerja yang nyaman dan kondusif agar selama proses mendidik dapat tersalurkan dengan baik dan optimal. Begitu dengan kualitas yang harus sesuai dengan kualifikasinya, yaitu melaksanakan peran dan fungsi sesuai dengan jabatannya. Bagi guru harus sudah menempuh pendidikan minimal S1, kemampuan akademik, kemampuan performance pembelajaran.

3. Proses

Untuk menciptakan iklim dan lingkungan yang kondusif, yaitu menjalin komunikasi yang baik pada sesama pendidik dan tentu menjalin menjalin komunikasi dengan siswa agar siswa dapat memperlakukan guru dengan baik begitupun sebaliknya. Karena peran guru di sekolah adalah sebagai pengganti orang tua jadi komunikasi adalah hal yang paling utama. Ketika semua sudah memenuhi peran dan tugasnya masing-masing maka akan optimal dan harapannya seperti itu.

4. Outpout

Prestasi akademik peserta didik di SDN Condongcatur sudah diraih hingga tingkat kecamatan, berbagai prestasi dari berbagai bidang kompetisi. Latar belakang peserta didik sendiri adalah dari kelompok menengah, dan beragam. Banyak sosial ekonomi dari pegawai negeri, swasta, buruh dan lain-lain. Hambatan atau kendala pasti selalu ada didalam sebuah organisasi menurut Bapak Tri Suhadi, untuk menghindari kendala tersebut upaya yang dilakukan kepala sekolah adalah meningkatkan kualitas yang berangkat dari input peserta didik.

5. Outcome

Angka peserta didik yang melanjutkan ke jenjang pendidikan berikutnya merata, dalam artian tidak seluruh peserta didik melanjutkan ke sekolah negeri. Peserta didik ada yang melanjutkan ke pesantren dan sekolah swasta lainnya.

\section{KESIMPULAN}

Berdasarkan dari pembahasan yang telah diuraikan, terdapat beberapa kesimpulan dalam penulisan makalah ini:

1. Komponen SD/MI adalah komponen pada sebuah aturan atau proses pendidikan yang mempunyai tanggung jawab secara komprehensif dalam menentukan berhasil tidaknya suatu langkah untuk mencapai tujuan pendidikan. Komponen SD/MI diantaranya ada tujuan, pendidik, peserta didik, materi, metode, media dan alat pendidikan, dan lingkungan pendidikan.

2. Karakteristik sekolah efektif yaitu kepemimpinan instruksional, menerapkan fungsi manajemen, fokus pada tujuan dan kepuasan pendidik. Komponen mutu SD/MI yaitu terdapat pada standar nasional pendidikan diantaranya standar pengelolaan, standar kompetensi lulusan, standar isi, standar roses, standar pendidik dan tenaga kependidikan, standar sarana dan prasarana, standar pembiayaan dan standar penilaian.

3. Dimensi kepemimpinan pendidikan ialah mampu bertransformasi dan dapat berpijak pada unsur humanistik yang berupa pemberdayaan pendidik serta memiliki keahlian dalam memajukan sekolah.

4. Relevansi kepemimpinan dan pendidikan dalam memberdayakan SDM adalah untuk memboyong organisasi atau sekolah pada tujuan yang telah ditetapkan sehingga dapat meningkatkan kualitas profesional dan terampil dalam menjalankan tugasnya.

5. Implementasi kepemimpinan untuk menjadikan sekolah efektif di SDN Condongcatur Yogyakarta telah memenuhi lima komponen yaitu konteks, input, output, proses dan 
outcome. Selain itu kepala sekolah untuk mewujudkan sekolah efektif ialah memiliki kesadaran diri pada peningkatan kualitas diri agar mampu bekerja secara efektif dan profesional.

\section{BIBLIOGRAPHY}

Anzizhan, S. (2004). Sistem Pengambilan Keputusan Pendidikan. Jakarta: Grasindo.

Engkoswara, \& Komariah, A. (2010). Administrasi Pendidikan. Bandung: Alfabeta.

Fitrah, M. (2017). Peran Kepala Sekolah Dalam Meningkatkan Mutu Pendidikan. Jurnal Penjaminan Mutu, 3(1), 31. https://doi.org/10.25078/jpm.v3i1.90

Hasibuan, M. (2016). Manajemen Sumber Daya Manusia. Jakarta: Bumi Aksara.

Herawan, E. (2016). Kepemimpinan Mutu Kepala Sekolah Dalam Peningkatan Mutu Pendidikan. PEDAGOGIA Jurnal Ilmu Pendidikan, 12(2), 51. https://doi.org/10.17509/pedagogia.v12i2.3329

Hijriah. (2016). Pengaruh Kepemimpinan Terhadap Pengembangan Sumber Daya Manusia Di Lingkup Sekertariat Dewan Perwakilan Rakyat Daerah Kabupaten Mamuju Utara. Jurnal Katalogis, 4(5). Retrieved from http://dx.doi.org/10.22487/j23022019,2016.v4.i5.6592

Indonesia, P. R. (2013). Peraturan Pemerintah Republik Indonesia Nomor 32 Tahun 2013 tentang Standar Nasional Pendidikan. Indonesia.

Lubis, A. H. (2017). Pelaksanaan Standar Pengelolaan Pendidikan Ditinjau dari Perencanaan Program pada Sekolah Menengah Kejuruan KARTIKA 1-1 PADANG. Jurnal Bahana Manajemen Pendidikan, 56(2), 1-12. https://doi.org/https://doi.org/10.23036/bmp.v6i2.8563

Marini, A. (2017). Manajemen Sekolah Dasar. Bandung: PT. Remaja Rosdakarya.

Moerdiyanto. (2007). Manajemen Sekolah Indonesia yang Efektif Melalui Penerapan Total Quality Mnagement. IMEC 2007 Proceedings. Retrieved from http://staff.uny.ac.id/sites/default/files/penelitian/Drs. Moerdiyanto, M.Pd./ARTIKEL MANAJEMEN SEKOLAH EFEKTIF.pdf

Ondi, S., \& Sobarudin. (2015). Konsep-Konsep Dasar Menjadi Unggul (I). Yogyakarta: Penerbit Deepublish.

Raharjo, S. B., \& Yuliana, L. (2016). Manajemen Sekolah Untuk Mencapai Sekolah Unggul Yang Menyenangkan: Studi Kasus Di Sman 1 Sleman Yogyakarta. Jurnal Pendidikan Dan Kebudayaan, 1(2), 203. https://doi.org/10.24832/jpnk.v1i2.769

Raihani. (2011). Kepemimpinan Sekolah Transformatif. Yogyakarta: LkiS Yogyakarta.

Riswandi. (2015). Pelatihan Manajemen Sekolah Sebagai Upaya Untuk Menciptakan Sekolah Efektif Pada Sekolah Dasar Di Kabupaten Tanggamus. Jurnal Tarbiyah, 22(1), 147-168. https://doi.org/http://dx.doi.org/10.30829/tar.v22i1.10

Rohmat. (2010). Kepemimpinan Pendidikan Konsep dan Aplikasi. Purwokerto: STAIN PRESS.

Sapa'at, A. (2012). Stop Menjadi Guru (I). Jakarta: PT. Tangga Pustaka.

Stronge, J. H., Richard, H. B., \& Catano, N. (2013). Kualitas Kepala Sekolah yang Efektif (I). Jakarta: PT. Indeks.

Suhadi, T. (2019). Wawancara. Yogyakarta.

Suhardiman, B. (2012). Studi Pengembangan Kepala Sekolah: Konsep dan Aplikasi. Jakarta: Rineka Cipta.

Syafril, \& Zen, Z. (2017). Dasar-Dasar Ilmu Pendidikan. Depok: Kencana.

Usman, H. (2011). Manajemen: teori, praktik, dan riset pendidikan (5th ed.). Jakarta: Bumi Aksara. 
Yusraini. (2012). Implementasi Manajemen Sumber Daya Manusia: Tenaga Pendidik Dan Kependidikan Untuk Meningkatkan Mutu Layanan Pendidikan. Jurnal Al-Ulum, 1.

Zuhri, M. M. (2014). Pengembangan Sumber Daya Guru Dan Karyawan Dalam Organisasi Pendidikan. Journal of Empirical Research In Islamic Education, 2(2), 205-221. https://doi.org/http://dx.doi.org/10.21043/quality.v2i2.2108 